\title{
Zinc and atopic dermatitis - a literature review
}

\section{Cynk i atopowe zapalenie skóry - przegląd piśmiennictwa}

\author{
Katarzyna Banaszczyk $\mathbf{k}^{1, \mathrm{~A}-\mathrm{F} \oplus}$ \\ 1 Collegium Medicum in Bydgoszcz, UMK in Toruń, Poland \\ A - Research concept and design, B - Collection and/or assembly of data, C - Data analysis and interpretation, \\ $D$ - Writing the article, E - Critical revision of the article, F - Final approval of article
}

Banaszczyk K. Zinc and atopic dermatitis - a literature review. Med Og Nauk Zdr. 2021; 27(3): 261-264. doi: 10.26444/monz/140160

\begin{abstract}
Introduction and objective. Atopic dermatitis is a chronic inflammatory disease that significantly reduces the quality of life of the affecte patients. The disease is characterized by the occurrence of eczema, increased pruritus and lichenization. Diagnosis is based on the diagnostic criteria of Hanifin and Rajka, which take into account the clinical picture of the disease. Atopic dermatitis often co-occurs with sleep and mood disorders. Recently, there have been scientific studies to clarify the association of atopic dermatitis with the level of zinc in the body. This review resents the importance of zinc in the proper functioning of human skin and its possible links to the pathogenesis and clinical advancement of atopic dermatitis.
\end{abstract}

Materials and method. Articles from PubMed, Scopus and article references from 1990-2020 were analyzed. Articles were selected on the topic of zinc supplementation in patients with atopic dermatitis and articles on the level of zinc in the serum, erythrocytes and hair in patients with atopic dermatitis.

Brief description of the state of knowledge. The review refers to scientific studies conducted on animals, in which the effect of a low supply of zinc on the course of the disease was determined. The review also refers to clinical trials determining the effect of zinc supplementation on the course of atopic dermatitis in patients, and describes the relationship between zinc levels in serum, hair and erythrocytes, and the severity of the disease.

Conclusions. The review indicates that zinc may have a significant impact on the course of inflammatory dermatoses, including atopic dermatitis. It is worth exploring this topic and conducting larger clinical trials because the results of currently available scientific research are promising.

\section{Key words}

zinc, atopy, atopic dermatitis

\section{Streszczenie}

Wprowadzenie i cel pracy. Atopowe zapalenie skóry to przewlekła choroba zapalna, która znacznie obniża jakość życia dotkniętych nią pacjentów. Atopowe zapalenie skóry charakteryzuje się występowaniem zmian wypryskowych, nasilonym świądem oraz lichenizacją. Rozpoznanie stawiane jest na podstawie kryteriów diagnostycznych Hanifina i Rajki, które biorą pod uwagę obraz kliniczny choroby. Atopowe zapalenie skóry często współwystępuje z zaburzeniami snu oraz zaburzeniami nastroju. W ostatnim czasie pojawiły się badania naukowe mające na celu wyjaśnienie związku atopowego zapalenia skóry z poziomem cynku w organizmie. Niniejsza praca przedstawia znaczenie cynku w prawidłowym funkcjonowaniu skóry człowieka oraz jego możliwe powiązania z patogenezą i zaawansowaniem klinicznym atopowego zapalenia skóry.

Metody przeglądu. Przeanalizowano artykuły z PubMed, Scopus oraz odniesienia do tekstów. Wybrano artykuły na temat suplementacji cynkiem u pacjentów z atopowym zapaleniem skóry oraz te dotyczące poziomu cynku w surowicy, erytrocytach i włosach u pacjentów z atopowym zapaleniem skóry. Przeanalizowano artykuły z lat 1990-2020.

Opis stanu wiedzy. Praca odnosi się do badań naukowych przeprowadzonych na zwierzętach, w których określono wpływ niskiej podaży cynku na przebieg choroby. Co więcej, praca ta nawiązuje do badań klinicznych ukazujących wpływ suplementacji cynku na przebieg atopowego zapalenia skóry u pacjentów oraz opisuje związek między poziomem cynku w surowicy, włosach i erytrocytach a zaawansowaniem choroby.

Podsumowanie. Przedstawione badania wskazują, że cynk może mieć istotny wpływ na przebieg dermatoz zapalnych, w tym atopowego zapalenia skóry. Warto zgłębić ten temat i przeprowadzić większe badania kliniczne w tym zakresie, ponieważ wyniki obecnie dostępnych badań naukowych są obiecujące.

\section{Słowa kluczowe \\ atopowe zapalenie skóry, cynk, atopy}

\footnotetext{
Address for correspondence: Katarzyna Banaszczyk, Collegium Medicum in Bydgoszcz, UMK in Toruń, Spółdzielcza 13A/5, 87-700, Aleksandrów Kujawski, Poland

E-mail: kbanaszczyk570@gmail.com

Received: 24.03.2021; accepted: 12.07.2021; first published: 23.07.2021
}

\section{INTRODUCTION}

Atopic dermatitis (AD) is a chronic, inflammatory, pruritic skin disease which affects $15-20 \%$ of children and $1-3 \%$ of adults [1]. It is believed that the basis of this disease are immunological abnormalities and genetic conditions that lead to damage to the epidermal barrier [2]. Atopic dermatitis 
is characterized by the occurrence of eczema, increased pruritus and lichenization. AD usually starts in childhood, and in a half of cases the disease begins between 3-6 months of age, has a chronic and recurrent course, in most cases there is a tendency to self-extinguishing of symptoms. In adults and older children, eczema lesions typically occur on elbow and knee bends, face and neck. On the other hand, in younger children (under 2 years of age), skin lesions more often affect the face. Diagnosis is based on the diagnostic criteria of Hanifin and Rajka, which take into account the clinical picture of the disease [3]. Due to persistent pruritus and skin lesions, $\mathrm{AD}$ is associated with a decrease in the quality of life of patients. It often co-occurs with sleep and mood disorders $[4,5]$. Scientific research is continuing to create effective treatment of AD and improve the quality of life of patients affected by this disease.

In recent years, scientific research appears to have clarified the role of zinc and its effect on the course of atopic dermatitis. The aim of this work is to present the role of zinc and its influence on the proper functioning of the skin, as well as the presentation of recent scientific studies that attempt to explain the relationship between zinc and atopic dermatitis. Articles from PubMed, Scopus and article references were analyzed. Articles were selected on the topic of zinc supplementation in patients with atopic dermatitis and articles on the level of zinc in the serum, erythrocytes and hair in patients with atopic dermatitis. Articles from 1990-2020 were analyzed. Search terms included 'atopic dermatitis', 'zinc', 'zinc deficiency', 'zinc supplementation', 'eczema', and 'atopic eczema'.

Zinc and its role in the proper functioning of the skin. Zinc is a very important micronutrient in the human body, it is a component of many enzymes and determines the proper course of cellular functions and metabolic reactions crucial for the body [6]. This microelement determines the correct structure of proteins, regulates the expression of many genes and is necessary for the proper functioning of the immune system $[7,8]$. Trace elements are essential for the proper functioning of the immune system. Due to its immunomodulatory action, the proportion of zinc is taken into account in the pathogenesis of inflammatory and autoimmune diseases. Activation of T lymphocytes, as well as the differentiation of helper lymphocytes (Th) into their various subgroups (Th1, Th2, Th17, regulatory T cells) depend on zinc homeostasis. Zinc deficiency leads to an increase in the level of IL-10, which in turn leads to an imbalance between the activity of Th1 and Th2 lymphocytes, in favour of Th2 lymphocytes. Secondly, zinc deficiency increases the level of IL-4, which in turn leads to increased activity of B lymphocytes and $\operatorname{IgE}$ antibodies, which affects the course of allergic diseases. $[9,10]$.

With regard to the influence of zinc on the immune system, it is worth being aware that the deficiency of this element may affect the course of viral diseases, including SARS-CoV-2 infection. As zinc deficiency is a worldwide phenomenon, the link between zinc deficiency and the COVID-19 pandemic is currently the subject of several studies that should be published soon. Moreover, zinc supplementation may play a role in the treatment of SARS-CoV-2 infection. In addition, studies show that people suffering from COVID-19 had significantly lower levels of zinc compared to healthy people. It was associated with a more than 5-fold increased probability of disease complications [11].
The symptoms of deficiency of this microelement include, among others: dry skin, hair loss, impaired wound healing and acrodermatitis enteropathica [12]. Interesting studies on zinc and atopic dermatitis have been carried out on mice in which zinc deficiency exacerbated skin eruptions, increased serum IgE levels, and increased cytokine production, such as IL-13 and IFN-gamma [13]. This may indicate that zinc deficiency may affect the barrier system of the skin and the immune system. What is more, this study carried out on mice shows that zinc deficiency may exacerbate atopic dermatitis.

The role of zinc in the proper functioning of the skin and in the course of atopic dermatitis has not yet been clearly explained. Zinc is part of the enzymes involved in the remodeling of the epidermis, and also plays a role in the expression of filaggrin, a key protein that is necessary to create a skin barrier, so important in atopic dermatitis [14]. Interestingly, zinc oxide may also have antibacterial activity against $S$. aureus [15]. Studies in mice also showed that zinc may reduce the level of pro-inflammatory cytokinez, such as IL- 6 and IL-1, and at the same time increase the level of antiinflammatory cytokines (IL-10) in mechanically damaged skin $[14,16]$.

Bearing in mind the above information on the effect of zinc on the proper functioning of the skin, it can be assumed that this microelement may have a significant impact on the course of dermatological diseases, including atopic dermatitis.

Zinc and atopic dermatitis - scientific reports. Kim et al. conducted a clinical study to determine the level of zinc in the hair of children with atopic dermatitis (AD), and to investigate the effectiveness of zinc administration in children with AD. 58 patients with confirmed diagnosis of $\mathrm{AD}$ were included in the study, their average age was 6.2 years. The children included in the study had AD from mild to moderate intensity (EASI $-<26)$. The control group consisted of 43 healthy children. Exclusion criteria were the use of topical calcineurin inhibitors, the topical use of steroids or antibiotics over the past two weeks, and the systemic use of anti-inflammatory drugs in the last 4 weeks.

The first stage of the study was to compare the content of zinc in hair in children with $\mathrm{AD}$ and in the control group. The average level of zinc in the hair was $113.10 \pm 33.36 \mu \mathrm{g} / \mathrm{g}$ in the group of patients with $\mathrm{AD}$ and $130.90 \pm 36.63 \mu \mathrm{g} / \mathrm{g}$ in the control group. Forty-one patients with $\mathrm{AD}(70.7 \%)$ had zinc levels below $130 \mu \mathrm{g} / \mathrm{g}$, while in the control group this was reported by 18 people (41.9\% of the group, respectively). It follows that atopic dermatitis was associated with a lower level of zinc in the hair compared to the control group.

The second stage of the study was to determine the effectiveness of zinc supplementation in patients with $\mathrm{AD}$, who in the first stage of the study showed a low level of this microelement. 41 patients with low levels of zinc and AD were randomly assigned to 2 groups. The first group (group A) - included patients who were supplemented with zinc, while patients from group B constituted a control group and remained without supplementation. 22 patients were assigned to group A and 19 patients to group B. Group A received $12 \mathrm{mg}$ of zinc in the form of zinc oxide, and supplementation with this microelement lasted 8 weeks. Patients in both groups received standard oral anti-histamines and topical moisturizers. After 8 weeks, in group A the level of zinc in hair increased from baseline value of $96.36 \pm 21.05 \mu \mathrm{g} / \mathrm{g}$ to 
$131.81 \pm 27.45 \mu \mathrm{g}$. In group $\mathrm{B}$, the level of zinc did not change significantly. Patients were examined by a dermatologist in the $2 \mathrm{nd}, 4$ th and 8 th week of the study. The assessment was based on the intensity of atopic dermatitis, Eczema Area and Severity Index, transepidermal water loss (TEWL) and visual analogue scale (VAS) for pruritus and sleep disorders. The AD severity scores improved significantly in patients who received zinc supplementation compared to the control group. In group A, EASI improved to $1.73 \pm 1.23$ at 8 weeks (baseline EASI score - 6.56 \pm 3.12 ). In group B, EASI declined to $3.29 \pm 2.77$ at 8 weeks (baseline score $-6.32 \pm 2.80$ ). The results of the EASI scale after 8 weeks varied significantly between groups A and B ( $\mathrm{p}=0.013 ; 0.044)$.

The above study shows that oral zinc supplementation can be effective in patients with atopic dermatitis with zinc levels in the hair. During 8-week oral zinc supplementation, no side effects of this therapy were reported [17].

Another study on zinc and atopic dermatitis was carried out by Hinks et al., the aim of which was to determine the level of zinc in the serum and hair of children with bronchial asthma and $\mathrm{AD}$, compared to healthy people. 40 children aged 2-12 participated in the study. 22 of them had bronchial asthma and 18 of them had AD. The control group of this study was 20 healthy children. Average serum and hair zinc concentrations were $70.3 \pm 13.2$ micrograms $/ 100 \mathrm{ml}$ and $157.5 \pm 23.0$ micrograms/gm for asthma and $65.9 \pm 11.7$ micrograms $/ 100$ $\mathrm{ml}$ and 164.8 , respectively. \pm 23.6 micrograms / gm in the case of atopic dermatitis. The level of zinc in children with bronchial asthma and AD was significantly lower compared to the control values $(88.4 \pm 11.0$ micrograms $/ 100 \mathrm{ml}$ and $194.5 \pm 18.6$ micrograms/gm). This study shows that asthma and atopic dermatitis were associated with a lower content of zinc in the body [18].

Karabacak et al. conducted a study aimed at determining the level of zinc in the serum and erythrocytes of patients with $\mathrm{AD}$, and investigating the relationship between the level of zinc and disease activity. 67 patients (34 women and 33 men) who had been diagnosed with $\mathrm{AD}$, using the diagnostic criteria of Hanifin and Rajka, were included in the study. The control group consisted of 49 healthy people. The study excluded patients taking zinc, systemic corticosteroid, antibiotics and systemic anti-inflammatory drugs. In the group of patients with $\mathrm{AD}$, the level of zinc in erythrocytes was clearly lower than in the control group (34.4 \pm 6.1 $\mu \mathrm{g} / \mathrm{g}$ of haemoglobin and $40.4 \pm 5.3 \mu \mathrm{g} / \mathrm{g}$ of haemoglobin). Interestingly, there was no statistical difference between the serum zinc level in patients with $\mathrm{AD}$ and the control group $(89.9 \pm 16.8$ and $96.1 \pm 17.6 \mu \mathrm{g} / \mathrm{dl}$, respectively). The severity of the disease was assessed using the AD point index (SCORAD), in which $\mathrm{AD}$ is defined as mild, moderate or severe if the SCORAD index is $<25,25-50$ and $>50$, respectively. In the group of patients with $\mathrm{AD}$, a negative correlation was found between the result of the SCORAD index and the level of zinc in erythrocytes. The lowest levels of zinc in erythrocytes were associated with the highest disease severity (SCORAD> 50). The negative relationship between the severity of the disease and the level of zinc in erythrocytes may suggest an immunopathological relationship between $\mathrm{AD}$ progression and intracellular metabolism of this microelement [19].

An interesting study on mice was carried out by Makiura et al. the aim of which was to study the impact of a diet with a reduced content of zinc on the course of $\mathrm{AD}$. In this study, an animal model of the AD was used. Mice fed with a reduced zinc feed were compared to mice receiving a standard diet. Mice fed with products with reduced zinc content showed more advanced dryness of the skin, increased transepidermal water loss, lower water content in the skin and elevated levels of immunoglobulin $\mathrm{E}$ in the blond, compared to mice receiving a standard diet. There were no significant differences in the weight of the animals or the weight of the main organs between the 2 groups. The haematological tests performed in both groups were normal, with the exception of an increased level of IgE immunoglobulin in the mice fed a diet with a reduced content of zinc [20]. This study shows that a diet with a reduced content of zinc may adversely affect the course of atopic dermatitis. The reduced content of zinc in the body may affect the course of AD.

The next interesting case-control study was described in an article by Gray et al. 105 children aged 1-12 years were qualified for the study. The research group consisted of children suffering from $\mathrm{AD}$ (atopic dermatitis, $\mathrm{n}=40$ ), and the control group - healthy children $(n=65)$. The concentration of zinc in the hair of the participants was assessed. Interesting results were obtained, because when assessing the groups as a whole, without specifying age groups, the concentration of zinc in the hair of healthy children and children with AD did not differ significantly. On the other hand, in the 5-12-year-old subgroup, the concentration of zinc in hair was lower in children with AD (median $175.35 \mu \mathrm{g} / \mathrm{g}$ ) than in healthy children (median $206.4 \mu \mathrm{g} / \mathrm{g}$ ) [21].

\section{CONCLUSIONS}

Despite many studies, little is known about the role of trace elements in allergic diseases and the relationship of these elements with the immune system. The clinical trials presented in this study allow us to believe that zinc plays an important role in the proper functioning of the skin, and has some influence on the course of atopic dermatitis. Many more scientific studies are needed to determine exactly how zinc modulates the course of the disease and how it can be used in supplementation for therapeutic purposes. The concentration of zinc in the hair differs significantly in the studies cited in this article. It is worth mentioning that currently there are no specific standards for the concentration of zinc in hair and erythrocytes. Moreover, it is still not known how low zinc levels may worsen the clinical symptoms of AD. Currently, there is insufficient clinical evidence for the positive effect of zinc on the course and advancement of $\mathrm{AD}$; therefore, the guidelines do not recommend supplementation of this element in patients. It is worth exploring this topic and conducting larger clinical studies, because the results of currently available scientific research are promising.

\section{REFERENCES}

1. Nutten S, Atopic Dermatitis: Global Epidemiology and Risk Factors. Ann Nutr Metab. 2015;66(suppl 1): 8-16. https://doi.org/10.1159/000370220. 2. Yang G, Kyung Seok J, Chang Kang H, et al. Skin Barrier Abnormalities and Immune Dysfunction in Atopic Dermatitis. Int J Mol Sci. 2020;21(8): 2867. https://doi.org/10.3390/ijms21082867

3. Nowicki R. ABC Atopic dermatitis. AZS in questions and answers. Termedia; 2015.

4. Holm JG, Agner T, Clausen ML, Thomsen SF. Quality of life and disease severity in patients with atopic dermatitis. J Eur Acad Dermatol Venereol. 2016; 30(10): 1760-7. https://doi.org/10.1111/jdv.13689 
5. Eckert L, Gupta S, Amand C, Gadkari A, Mahajan P, Gelfand JM. Impact of atopic dermatitis on health-related quality of life and productivity in adults in the United States: An analysis using the National Health and Wellness Survey. J Am Acad Dermatol. 2017; 77(2): 274-9. https://doi. org/10.1016/j.jaad.2017.04.019

6. Saper RB, Rash R. Zinc: an essential micronutrient. Am Fam Physician. 2009; 79: 768-772.

7. Maares M, Haase H. Zinc and immunity: An essential interrelation. Archives of biochemistry and biophysics. 2016; 611: 58-65. https:// www.doi.org/10.1016/j.abb.2016.03.022

8. Gray NA, Dhana A, Stein DJ, Khumalo NP. Zinc and atopic dermatitis: a systematic review and meta-analysis. J Eur Acad Dermatol Venereol. 2019; 33(6): 1042-1050. https://www.doi.org/10.1111/jdv.15524

9. Maywald M, Rink L. Zinc homeostasis and immunosenescence. J Trace Elem Med Biol. 2015; 29: 24-30. https://www.doi.org/10.1016/j. jtemb.2014.06.003

10. Dhaliwal S, Nguyen M, Vaughn AR, Notay M, Chambers CJ, Sivamani RK. Effects of Zinc Supplementation on Inflammatory Skin Diseases: A Systematic Review of the Clinical Evidence. Am J Clin Dermatol. 2020; 21(1): 21-39. https://www.doi.org/10.1007/s40257-019-00484-0

11. Joachimiak MP. Zinc against COVID-19? Symptom surveillance and deficiency risk groups. PLoS Negl Trop Dis. 2021; 15(1): e0008895. https://www.doi.org/10.1371/journal.pntd.0008895

12. Sauer AK, Hagmeyer S, Grabrucker AM. Zinc Deficiency, Nutritional Deficiency. Intact open science. 2016. https://www.doi.org/10.5772/63203

13. Takahashi H, Nakazawa M, Takahashi K, Aihara M, Minami M, Hirasawa T, et al. Effects of zinc deficient diet on development of atopic dermatitis-like eruptions in DS-Nh mice. J Dermatol Sci. 2008; 50(1): 31-9. https://www.doi.org/10.1016/j.jdermsci.2007.11.002
14. Maarouf M, Vaughn AR, Shi VY. Topical micronutrients in atopic dermatitis-An evidence-based review. Dermatol Ther. 2018; 31(5): e12659. https://www.doi.org/10.1111/dth.12659

15. Kadiyala U, Turali-Emre ES, Bahng JH, Kotov NA, VanEpps JS. Unexpected insights into antibacterial activity of zinc oxide nanoparticles against methicillin resistant Staphylococcus aureus (MRSA). Nanoscale. 2018; 10(10): 4927-39. https://www.doi.org/10.1039/ c7nr08499d

16. Vaughn AR, Foolad N, Maarouf M, Tran KA, Shi VY. Micronutrients in Atopic Dermatitis: A Systematic Review. J Altern Complement Med. 2019; 25(6): 567-577. https://www.doi.org/10.1089/acm.2018.0363

17. Kim JE, Yoo SR, Jeong MG, Ko JY, Ro YS. Hair zinc levels and the efficacy of oral zinc supplementation in patients with atopic dermatitis. Acta Derm Venereol. 2014; 94(5): 558-62. https://www. doi.org/10.2340/00015555-1772

18. el-Kholy MS, Gas Allah MA, el-Shimi S, et al. Zinc and copper status in children with bronchial asthma and atopic dermatitis. J Egypt Public Health Assoc. 1990; 65: 657-68.

19. Karabacak E, Aydin E, Kutlu A, Ozcan O, Muftuoglu T, Gunes A, et al. Erythrocyte zinc level in patients with atopic dermatitis and its relation to SCORAD index. Adv Dermatol Allergol. 2016; 33(5): 349-52. https:// www.doi.org/10.5114/ada.2016.62841

20. Makiura M, et al. Atopic dermatitis-like symptoms in HR-1 hairless mice fed a diet low in magnesium and zinc. J Int Med Res. 2004; 32: 392-399. https://www.doi.org/10.1177/147323000403200407

21. Gray NA, Esterhuizen TM, et al. Investigating hair zinc concentrations in children with and without atopic dermatitis. S Afr Med J. 2020; 110(5): 409-415. https://doi.org/10.7196/SAMJ.2020.v110i5.14308 